\title{
Implementation of Physical Education Learning in Down Syndrome Students at SLB YPAC Medan
}

\author{
Akhmadi Malaon Lubis \\ Department of Sport Education \\ Post Graduate Program \\ UniversitasNegeri Medan \\ (UNIMED) \\ Medan, Indonesia
}

\author{
Indra Kasih \\ Department of Sport Education \\ Post Graduate Program \\ UniversitasNegeri Medan \\ (UNIMED) \\ Medan, Indonesia
}

\author{
Nurhayati Simatupang \\ Department of Sport Education \\ Post Graduate Program \\ UniversitasNegeri Medan \\ (UNIMED) \\ Medan, Indonesia
}

\begin{abstract}
Abstrak- The purpose of this study was to find out how the implementation of physical education learning in mentally retarded students at YPAC Medan Special School (SLB). The method used in this study uses a qualitative approach. The subjects of this study were physical education teachers and mild tuna students. Data collection techniques using observation and interview data. Based on the results of research found that students are still undeveloped from the educational process such as students who have not been able to read, the teacher does not have a special background education which makes it difficult for teachers to teach mentally disabled children, and teachers should have a special teacher in implementing learning. The conclusion of this study is that the creativity of physical education teachers is very much needed in making learning that stimulates the development of student and motoric knowledge of students, the selection of activities for learning physical education is still difficult to determine by physical education teachers. This is due to the condition and situation of mentally disabled children who every day are difficult to predict. Therefore physical education teachers must pay attention to children's intellectual, social and emotional levels.
\end{abstract}

Keywords: Learning. Physical education. Middle School Students,

\section{INTRODUCTION}

Children with special needs are children who need special treatment due to developmental disorders and abnormalities experienced by children. Regarding the term disability, children with special needs are children who have limitations in one or several abilities both physical and deaf, as well as psychological, such as autism and ADHD (1). The results of the analysis from Global Burden Of Disesase in 2004 that $15.3 \%$ of the world population (around 978 million people) had moderate or severe disability and $2.9 \%$ or around 185 million had severe disabilities. While from the 2012 Susenas data, it was $2.45 \%$ that the Indonesian population had disabilities $( \pm 3,000,0000$ people). Based on Susenas, in 2012 persons with disabilities are persons who experience more than one type of limitation (2)

Special physical or mental abnormalities in children with special needs who have developmental needs (tuna grahita) require special education services in accordance with the Law of the Republic of Indonesia concerning the National Education System No. 2 of 1989 (in article 11 paragraph 4 and article 38) and reaffirmed in the RI Law concerning National Education System No. 20 of 2003 in article 3 paragraph 1 that: special education is education for students who have a level of difficulty in following the learning process because of physical, emotional, mental, social abnormalities and / or have potential intelligence and special talents (Bandi, 2006: 55).

Mentally disabled children crave a decent life, want harmonious growth and development. Therefore they also need education and guidance to become mature human beings and become citizens who can participate in the development of their nation and country. Education for children with special needs requires a separate service pattern, especially for children with functional development (children with developmental impairment), developmental hendaya refers to a certain condition with the existence of intelligence and adaptive functions, by showing various problems with cases different cases (Bandi, 2006: 145). Education for children with disabilities can be done in family, community (non-formal), and in school (formal). Formal education for children with disabilities is usually given by foundations or special schools (SLB). Each SLB has an educational curriculum program in rehabilitating, training, and educating disabled children, including physical education programs for disabled children (adaptive physical education).

The goal of mentally retarded children according to Dinie (2016: 21) is, as follows: 1) The purpose of education for mild mentally retarded children is so that children can take care and develop themselves, and can get along in the community. 2) The purpose of the education of moderate mentally retarded 
children is for children to take care of themselves; like eating drink, and can get along with family members and neighbors. 3) The purpose of the education of children with severe and very severe mental retardation is to be able to take care of themselves in a simple manner such as giving signs or words when they want something, such as eating and pooping.

The following are more specific characteristics of mentally retarded children based on the severity of the disorder according to Dinie (2016: 18-19), namely: 1) Able to educate. Able to educate is an educational term used to classify mild mental retardation. They still have the ability to be educated in a simple (basic) academic field that is reading, writing, and counting. Mampudidik children have maximum abilities equivalent to 12-year-olds or 6th grade elementary school students, if they get appropriate services and tutoring, students can afford to graduate elementary school, 2) Mampulatih. Physical retardation often has or is accompanied by physical and sensory abnormalities, even almost all children who have abnormalities with clinical types are included in the training group so it is very easy to detect trapped children, because their physical appearance (outward appearance) is different from normal children. the same age. Academic ability of trained children cannot take lessons even in simple ways such as reading, writing, and counting, 3) Need to be treated. Children need care is the most severe classification of mentally retarded children, if in medical terms it is called an idiot. Nursing children have intelligence capacity below 25 and are not able to train any skills.

Physically mild mentally retarded children are not different from normal children in general but are psychologically different. special characteristics. According to Siti Fatimah (2017, Vol 4. No 2. Hal 139) dividing the characteristics or characteristics of mentally retarded children into three parts, namely physical, psychological and social characteristics described as follows: 1) Physical characteristics appear to be normal children, only a few experiencing delays in sensomotor abilities, 2) Psychic characteristics are difficult to think abstractly and logically. Lack of analytical skills, weak associations, inability to control feelings, easily influenced, less harmonious personality because they are unable to judge good and bad, 3) Their social characteristics are able to get along, adjust in an environment that is not limited to the family, but there are those who are able to be independent in society, able to do simple work and do it fully as an adult. Ability in education includes being able to educate.

Based on several opinions stated above, it can be concluded that in general mild mental retardation children have the following characteristics: a. The physical characteristics of mild mentally retarded children appear to be normal children, only slightly experiencing delays in sensory ability.

b. Psychological characteristics of mild mentally retarded children include: low thinking ability, weak attention and memory, so that they have difficulty working on tasks that involve their mental and intellectual functions, lack vocabulary, and are unable to think abstractly.

c. The social characteristics of mild mentally retarded children are able to get along, adjust to the environment that is not limited to the family, but there are those who are able to be independent in the community, able to do simple work and do it fully as an adult.

To carry out the duties and responsibilities, the teacher has a very important role in children with special needs for mental retardation. The existence of children with special needs for mental retardation is usually always left behind with normal children in general. Additional tasks of a physical education teacher must be able to stimulate the development of intelligence, mental, social and physical emotions of mentally retarded children.

In carrying out the educational goals for mentally disabled children it is not as easy as when carrying out the educational process for normal children in general. As in the focus of this research wherein, researchers take the problem of learning physical education in mildly mentally retarded children. Physically mild mentally retarded children are not different from normal children in general but are psychologically different. But in learning many are not able to run it well.

Education for mentally retarded children is very important because they have a level of intelligence below the average normal child, thus education for mentally disabled children requires curriculum, teaching staff, and special facilities that have been adjusted to their level of limitations.

Adaptive physical education in mentally retarded children involves physical education teachers who have received special training in adaptive physical education and can arrange teaching programs so that they can be adapted to the conditions of children with limitations, so mentally disabled children must be given more specialized treatment. In addition the teacher must also pay attention to the factors of growth and development of the child, the ability of the teacher, the limited facilities and infrastructure as well as the development of sports, health problems according to local circumstances so that they can nurture the talents and interests of mentally retarded children.

To carry out the duties and responsibilities, the teacher has a very important role in children with special needs for mental retardation. The existence of children with special needs for mental retardation is usually always left behind with normal 
children in general. Additional tasks of a physical education teacher must be able to stimulate the development of intelligence, mental, social and physical emotions of mentally retarded children.

\section{RESEARCH METHODS}

The research approach used is a qualitative approach. The author is interested in researching the implementation of YPAC SLB education in Medan, information about this is still minimal. Therefore, a qualitative approach is more suitable for use. The subjects in this study were the mentally disabled students in the YPAC SLB Medan category and. Observation on children is the main means of data collection. Interviews with others were conducted to check the validity of the main data and to obtain other supporting data, namely interviews with parents and teachers.

\section{DISCUSSION}

During this time the learning activities carried out at SLB YPAC Medan, especially for children with mild mental retardation are still limited to conventional learning with the assistance of $\mathrm{Mr} / \mathrm{Ms}$ Teachers who intensively educate students. The curriculum designed for students is not all implemented in concrete or functional forms, some are still applied using conceptual. This has implications for children's learning motivation that is low, bored quickly, and quickly forgets because the emphasis on learning material is only done in one direction from the teacher to students, and the learning material delivered is not interesting.

Mentally retarded students at SLB YPAC Medan generally have learning barriers that include barriers related to developmental problems: cognitive, motoric and adaptive behavior. Learning difficulties for children with mental retardation occur because children's motor responses do not develop into motor patterns, consequently the motor skills of children with low mental retardation are occasionally less varied. Every child who has more needs, such as mental retardation, has different abilities, depending on the condition of the body.

Based on observations carried out by researchers, there were found several problems where:

1. Very much needed creativity of physical education teachers in making learning that stimulates the development of students' knowledge and motoric students. Because mentally retarded children look like normal but learning problems that are caused by obstacles to the development of intelligence, mental, social and physical emotions.
2. There are many students who are still undeveloped from the educational process such as students who have not been able to read, it can be seen from students who have difficulty working on teacher's instructions and understanding the teacher's commands. So that it is difficult to achieve learning goals.

3. The purpose of education for mild mentally retarded children is so that children can take care and develop themselves, and can get along in the community. But this has not been well realized in the field. The fact that researchers found, there are still many things that need to be addressed in carrying out the educational process given to mild mentally retarded children such as the application of games that educate students' understanding.

4. The teacher does not have a special background education which makes it difficult for the teacher to teach mentally disabled children, and the teacher should have a special teacher in implementing learning.

5. The selection of activities for physical education learning is still difficult to determine by physical education teachers. This is due to the condition and situation of mentally disabled children who every day are difficult to predict. Therefore physical education teachers must pay attention to children's intellectual, social and emotional levels.

\section{CONCLUSION}

Mentally disabled children crave a decent life, want harmonious growth and development. Therefore they also need education and guidance to become mature human beings and become citizens who can participate in the development of their nation and country. Education for children with special needs requires a distinctive service pattern, especially for children with functional developmental benefits. It is very necessary for the creativity of physical education teachers to make learning that stimulates the development of students 'knowledge as well as students' motor skills. Because mentally retarded children look like normal but learning problems that are caused by obstacles to the development of intelligence, mental, social and physical emotions. The purpose of education for mild mentally retarded children is so that children can take care and foster themselves, and can get along in the community. But this has not been well realized in the field. The fact that researchers found, there are still many things that need to be addressed in carrying out the educational process given to mild mentally retarded children such as the application of games that educate students' understanding. The selection of activities for physical education learning is still difficult to determine by physical education teachers. This is 
due to the condition and situation of mentally disabled children who every day are difficult to predict. Therefore physical education teachers must pay attention to children's intellectual, social and emotional levels.

\section{REFERENCE}

[1] Dinie Ratri Desiningrum. 2016. Psikologi Anak Berkebutuhan Khusus. Yogyakarta: Psikosain
[2] Sumber Pusat Data dan Informasi Kesehatan RI Tahun 2014

[3] UU RI tentang Sistem Pendidikan Nasional No. 20 Tahun 2003

[4] Bandi Delphie. 2006. Pembelajaran Anak Tunagrahita. Bandung: Refika Aditama.

[5] UU RI tentang Sistem Pendidikan Nasional No. 20 Tahun 2003

[6] Dinie Ratri Desiningrum. 2016. Psikologi Anak Berkebutuhan Khusus. Yogyakarta: Psikosain.

[7] Dinie Ratri Desiningrum. 2016. Psikologi Anak Berkebutuhan Khusus. Yogyakarta: Psikosain 